\title{
Buriti of the cerrado of Minas Gerais, Brazil: physical and chemical characterization and content of carotenoids and vitamins
}

\author{
Fabiana Rossini HAMACEK ${ }^{1}$, Ceres Mattos DELLA LUCIA ${ }^{1}$, Bárbara Pereira da SILVA ${ }^{1 *}$, \\ Ana Vládia Bandeira MOREIRA ${ }^{1}$, Helena Maria PINHEIRO-SANT’ANA ${ }^{1}$
}

\begin{abstract}
The fruit species of the Brazilian Cerrado, such as buriti (Mauritia vinifera), occupy a prominent position in the ecosystem since they contribute to the economic potential of the region and have high nutritional value. We aimed to evaluate the physical characteristics, chemical composition and content of vitamin C, carotenoids, vitamin E and folates in pulp of buriti from the Brazilian Cerrado of Minas Gerais, Brazil. The length, diameter, mass and fruit yield were evaluated. The titratable acidity was determined by volumetric neutralization; $\mathrm{pH}$ by potentiometry; soluble solids by refractometry; moisture using an oven; ash using a muffle furnace; proteins by the micro-Kjeldhal method; total dietary fiber by the gravimetric non-enzymatic method and lipids with a Soxhlet extractor. Vitamin $C$ and carotenoids were analyzed by high performance liquid chromatography with detection by diode array (HPLC-DAD) and vitamin E and folates by HPLC with fluorescence detection. Buriti pulp showed $12.13 \mathrm{~g} .100 \mathrm{~g}^{-1}$ of lipids and $74.86 \mathrm{~g} .100 \mathrm{~g}^{-1}$ of moisture. Also, the fruit showed high content of dietary fiber, carotenoids, vitamin $\mathrm{C}$, vitamin $\mathrm{E}$ and folates. Buriti can contribute to the adequate intake of fiber and vitamins and to preventing the incidence of disorders, especially those more frequent in native populations of the Cerrado.
\end{abstract}

Keywords: Mauritia vinifera; vitamin C; vitamin E; folates; HPLC.

Practical Application: Buriti can contribute to the adequacy of intake of fiber and vitamins and prevent several disorders.

\section{Introduction}

The dozens of native fruit species from the Brazilian Cerrado occupy a prominent position in the ecosystem, for they constitute a potential source for economical exploration, due to their popular acceptance and important nutritional value (Schiassi et al., 2018). The fruits found in the Cerrado present peculiar characteristics, such as varied shapes, attractive colours and sui generis flavours. Besides the sensory characteristics that make their consumption appealing, the fruits are noteworthy for being potential sources of carotenoids and other vitamins, thus contributing for human health (Schiassi et al., 2018).

Some carotenoids, such as $\alpha$-carotene, $\beta$-carotene and $\beta$ - cryptoxanthin, found in fruits, also present pro-vitamin A activity (Yamagata, 2017). The fruits from the Cerrado can also be considered excellent sources of vitamin $\mathrm{C}$, an ascorbic acid (AA) in its main biologically active form, though its oxidized form, dehydroascorbic acid (DHA), can also present vitamin activity (Schiassi et al., 2018; Hamacek et al., 2014). Vitamin C is one of the most important antioxidants found in fruits, helping prevent non-communicable chronic diseases such as diabetes and cardiometabolic diseases (Pearson et al., 2017).

Vitamin E, composed of four tocopherols ( $\alpha, \beta, \gamma$ and $\delta$-tocopherols) and four tocotrienols ( $\alpha, \beta, \gamma$ and $\delta$-tocotrienols), is also considered an important antioxidant found in fruits. This vitamin is able to stop chain reactions of free radicals and to protect cytoplasmic membranes from oxidation, thus reducing the risk of progression of several types of cancer and pre-cancer lesions. It also presents important activity on the modulation of cardiovascular diseases, as well as reducing cholesterol blood levels (Galli et al., 2017; Mangialasche et al., 2012). The folates can also be found in those fruits and present functions on several metabolic processes in human organism, being essential in the foresight and reduction of the risk of bad formation of the neural tube during gestating (Refsum, Smith, 2017).

Among the fruit species found on Brazilian Cerrado that can contribute as a source of carotenoids and vitamins it is noteworthy the buriti (Mauritia vinifera), a native palm tree, also known as miriti, carandá-guaçú, carandaíguaçú, muriti, palmeira-buriti, palmeira-dos-brejos, mariti, bariti e meriti (Schiassi et al., 2018; Almeida et al., 1998). Buriti’s pulp, soft and orange, can be eaten in natura or as flour, being also used in manufacture of candy, jam, juice and ice cream. The oil extracted from its pulp has a pleasant flavour and odour and can be used in cooking, and also used to treat burns and as adjuvant in sun protection (Pardauil et al., 2017). 
Despite the use of buriti pulp for various purposes, there is little data about the nutritional value of fruits found in the Cerrado of Minas Gerais, especially in relation to their content of vitamins and carotenoids obtained using reliable methods of analysis such as high-performance liquid chromatography (HPLC). The objective of this study was to evaluate the physical and physico-chemical elements and the vitamins and carotenoids content in buriti grown in Minas Gerais, Brazil.

\section{Materials and methods}

\subsection{Raw material, collection and preparation of samples}

Buriti fruits (Mauritia vinifera) were collected randomly after naturally falling from palm trees, during the harvest season (May to August, in the morning), in an area of native vegetation typical of the Savannah, located in the northern region of the state of Minas Gerais, Brazil, in the city of Januária (south latitude $15^{\circ} 29^{\prime}$ and west longitude $44^{\circ} 21^{\prime}$ ) (Hamacek et al., 2014). To obtain five repetitions, the collection area was divided into subareas, and approximately $1.5 \mathrm{~kg}$ of fruit was collected from each sub-area (Hamacek et al., 2013a).

In the laboratory, the fruits were selected according to the degree of maturation and absence of injuries, based on the parameters of color and texture characteristics of the fruit (peel firm and reddish brown). Subsequently, after two days immersed in water in order to soften the shell, the fruit pulp was obtained by manually removing peel and seeds using a stainless-steel knife. The pulp obtained was blended using a domestic food processor (Faet Multipratic, MC5, Brazil), packed in polyethylene bags and stored at $\left(-18 \pm 1^{\circ} \mathrm{C}\right)$ (Hamacek et al., 2013a).

\subsection{Physical and physicochemical characterize}

Individual measurements of longitudinal and transverse diameter were carried out on 30 buritis fruits using a digital caliper rule (Mitutoyo, Brazil). The mass of the whole fruit, pulp, bark and seeds was obtained by individual direct weighing on a semi-analytical balance (Gehaka, BG 2000, Brazil). The pulp yield was calculated using the equation [(mass pulp / mass of the whole fruit) $\times 100$ ] (Hamacek et al., 2013a).

The physic-chemical analyses were performed in three repetitions. Titratable acidity (TA), soluble solids (SS), $\mathrm{pH}$, moisture, ash, protein, lipids and total dietary fiber were determined (Association of Official Analytical Chemists, 2012). Carbohydrate concentrations were estimated by the equation: $[100-(\%$ moisture $+\%$ fat $+\%$ protein $+\%$ total dietary fiber $+\%$ ash $)]$. The total energy was estimated considering the conversion factors of $4 \mathrm{kcal} \cdot \mathrm{g}-1$ for protein and carbohydrate, and $9 \mathrm{kcal} \cdot \mathrm{g}-1$ for lipids (Association of Official Analytical Chemists, 2012; Hamacek et al., 2014).

\subsection{Extraction and analyses of carotenoids and vitamins}

During extraction and analysis, the samples and extracts were protected from both sunlight and artificial light with the use of amber glass bottles, aluminum foil and blackout curtains; they were also protected from oxygen by using lids and environments with nitrogen gas in glass bottles (Hamacek et al., 2014).
The occurrence and content of the $\alpha$-carotene, $\beta$-carotene, $\beta$ cryptoxanthin and lycopene were investigated in the buriti pulp. Extraction was performed using the method proposed by Rodriguez-Amaya (1999).

Carotenoid analysis was carried out by HPLC using the chromatographic conditions developed by Pinheiro-Sant'Ana et al. (1998), including the following chromatographic conditions: HPLC system (Shimadzu, SCL 10AT VP, Japan) comprised of a high-pressure pump (Shimadzu, LC-10AT VP, Japan), autosampler with a $50 \mu \mathrm{L}$ loop (Shimadzu SIL-10AF, Japan) and diode array detector (DAD) (Shimadzu SPD-M10A, Japan); chromatographic column, Phenomenex Gemini RP-18 (250 mm $\times 4.6 \mathrm{~mm}, 5 \mathrm{~mm})$, fitted with a guard column, RP-18 Phenomenex ODS column $(4 \mathrm{~mm} \times 3 \mathrm{~mm})$. The mobile phase consisted of methanol: ethyl acetate: acetonitrile $(70: 20: 10, \mathrm{v} / \mathrm{v} / \mathrm{v})$ with a flow of $2.0 \mathrm{~mL} \cdot \mathrm{min}^{-1}$ and a run time of $15 \mathrm{~min}$. Chromatograms were obtained at $450 \mathrm{~nm}$ (Hamacek et al., 2013b).

Vitamin A values were calculated according to the recommendations of the Institute of Medicine (2001), in which 1 Retinol Activity Equivalent (RAE) corresponds to $1 \mu \mathrm{g}$ of retinol, $12 \mu \mathrm{g}$ of $\beta$-carotene, or $24 \mu \mathrm{g}$ of other provitamin A carotenoids (Hamacek et al., 2013b).

Extraction and analysis of vitamin $\mathrm{C}$ were performed according to the methods proposed by Campos et al. (2009). The occurrence and content of ascorbic acid (AA) and dehydroascorbic acid (ADA) in buriti pulp were investigated. Analyses of vitamin C were performed using the same HPLC system used for analysis of carotenoids and the chromatographic conditions used were: HPLC-DAD system, chromatographic column: RP-18 Lichrospher $100(250 \mathrm{~mm} \times 4 \mathrm{~mm}, 5 \mu \mathrm{m})$ (Hamacek et al., 2013a). The mobile phase consisted of ultrapure water with $1 \mathrm{mM} \mathrm{NaH} \mathrm{PO}_{4}, 1 \mathrm{mM}$ EDTA and $\mathrm{pH}$ adjusted to 3.0 with $\mathrm{H}_{3} \mathrm{PO}_{4}$, and a mobile phase flow rate of $1.0 \mathrm{~mL} \cdot \mathrm{min}^{-1}$. Chromatograms were obtained at $245 \mathrm{~nm}$ (Hamacek et al., 2013a).

Extraction and analysis of the eight components of vitamin E ( $\alpha, \beta, \gamma$ and $\delta$-tocopherols and $\alpha, \beta, \gamma$ and $\delta$-tocotrienols) was performed according to Pinheiro-Sant'Ana et al. (2011). The chromatographic conditions used for analysis included: HPLC system (Shimadzu SCL 10AD VP, Japan); fluorescence detection (excitation at $290 \mathrm{~nm}$ and emission at $330 \mathrm{~nm}$ ); Luna chromatography column (Phenomenex Si60, $250 \mathrm{~mm} \times 4 \mathrm{~mm}, 5 \mu \mathrm{m}$ ), fitted with a guard column (Phenomenex Si60, $4 \mathrm{~mm} \times 3 \mathrm{~mm}$ ); a mobile phase composed of hexane: isopropanol: acetic acid, 98.9: $0.6: 0.5$, and a mobile phase flow rate of $1.0 \mathrm{~mL} \cdot \mathrm{min}^{-1}$. The total content of vitamin $\mathrm{E}$ was calculated by sum of the components of vitamin E identified in the samples (Hamacek et al., 2013b).

The extraction, purification, and analysis deconjugation three forms of folate tetrahydrofolate (THF), 5-methyltetrahydrofolate (5-MTHF) and 5-formyltetrahydrofolate (5-FTHF) in the buriti pulp were investigated (Della Lucia et al., 2010). The analysis was performed using folates in the same system used for analysis of vitamin $\mathrm{E}$, which in this case was also equipped with a helium degassing system for the mobile phase (Shimadzu DGU-2). The chromatographic conditions used for analyses included: Shim Pack 100 RP18 chromatographic column ( $150 \mathrm{~mm}$ x $4.6 \mathrm{~mm}, 4.6 \mu \mathrm{m})$ (Merck, Germany), mobile phase composed of a binary gradient 
containing phosphate buffer solution $\left(\mathrm{NaH}_{2} \mathrm{PO}_{4} 30 \mathrm{mM}, \mathrm{pH}\right.$ adjusted to 2.3 with $\mathrm{H}_{3} \mathrm{PO}_{4}$ ) as eluent $\mathrm{A}$, and acetonitrile as eluent B (Hamacek et al., 2013b). The gradient utilized was as follows: from $0-5$ minutes $94 \%$ of the eluent $A+6 \%$ of the eluent B; $5-25$ minutes, linear gradient to $75 \%$ of $A+25 \%$ of $B$; $25-33$ minutes, $75 \%$ of $\mathrm{A}+25 \%$ of $\mathrm{B} ; 33-35$ return to initial conditions followed by stabilization until $50 \mathrm{~min}$. Mobile phase flow was $0.7 \mathrm{~mL} \cdot \mathrm{min}^{-1}$ and fluorescence detection occurred with excitation at $290 \mathrm{~nm}$ and emission at $360 \mathrm{~nm}$. The mobile phase was degassed with helium for 15 minutes at $100 \mathrm{kpa}$ before initiating the analyses, and at $50 \mathrm{kpa}$ during the runs (Della Lucia et al., 2010; Hamacek et al., 2013b).

\subsection{Identification and quantification of carotenoids and vitamins}

For qualitative identification of the compounds injections of the carotenoids and vitamins standards were performed and the retention times obtained for the standards were compared with the samples. Furthermore, for the carotenoids and AA, the absorption spectra of the standards and of the corresponding peaks in samples were compared by using the DAD. For the different forms of folate and vitamin E, co-chromatography was used.

Quantification of the compounds was carried out using an external standardization curve. Appropriate dilutions were made from the standard solutions in order to achieve concentrations comparable with those observed in the buriti in natura pulp. For this, solutions of each compound present in the pulp ( $\alpha$-carotene, $\beta$-carotene, AA, $\alpha$-tocopherol, $\alpha$-tocotrienol, $\beta$-tocopherol, $\gamma$-tocopherol, THF and 5-FTHF) were prepared in different concentrations (Hamacek et al., 2013a).

Construction of the standard curves was performed by injection, in duplicate, of six increasing concentrations of the standard solutions (Hamacek et al., 2013b) in the range from 0.013 to $0.393 \mu \mathrm{g}$ for $\alpha$-carotene, 0.003 to $0.112 \mu \mathrm{g}$ for $\beta$-carotene, 0.155 to $7.750 \mu \mathrm{g}$ for AA, 0.0010 to $0.1042 \mu \mathrm{g}$ for $\alpha$-tocopherol; 0.0020 to $0.5100 \mu \mathrm{g}$ for $\alpha$-tocotrienol; 0.0037 to $0.1120 \mu \mathrm{g}$ for $\beta$-tocopherol; 0.0035 to $0.1040 \mu \mathrm{g}$ for $\mathrm{y}$-tocopherol; 0.00004 to $0.04622 \mu \mathrm{g}$ for THF and 0.00003 a $0.03312 \mu \mathrm{g}$ for 5FTHF. Thus, there was a linear correlation between the peak areas and the concentrations of each compound injected.

The quantification of compounds in buriti was performed from the analytical curve and regression equations for a-carotene $\left(y=2120957.979 x+9747.426 ; R^{2}=0.999\right)$, $\beta$-carotene $\left(y=1421302.230 x+3563.819 ; R^{2}=0.999\right)$; AA ( $\left.y=1394501.207 x-115382.946 ; R^{2}=0.993\right) ; \alpha$-tocopherol $\left(y=93284137.0896 x+47566.8009 ; R^{2}=0.997\right), \alpha$-tocotrienol $\left(\mathrm{y}=24797142.844 \mathrm{x}+285288.289 ; \mathrm{R}^{2}=0.998\right)$ (Hamacek et al., 2014); $\beta$-tocopherol $\left(\mathrm{y}=69128704.3544 \mathrm{x}-12630.4206 ; \mathrm{R}^{2}=0.997\right)$; $\gamma$-tocopherol $\left(\mathrm{y}=234829959.3330 \mathrm{x}+731230.4290 ; \mathrm{R}^{2}=0.997\right)$; THF $\left(\mathrm{y}=942240050.58 \mathrm{x}-162371.44 ; \mathrm{R}^{2}=0.996\right)$ and 5 -FTHF $\left(y=710036264.81 x-1088694.36 ; R^{2}=0.996\right)$ (Hamacek et al., 2013b). The real concentration was determined by calculations based on the dilutions utilized (Hamacek et al., 2013b).

\subsection{Quality control of the analytical methods}

Recovery tests, linearity, repeatability, limit of detection (LOD) and limit of quantification (LOQ) were performed for quality control of the analytical methods used in the analysis of vitamins (Hamacek et al., 2013a).

Recovery tests were carried out by addition of standards ( $\alpha$-carotene, $\beta$-carotene, AA, $\alpha$-tocopherol, $\alpha$-tocotrienol, $\beta$-tocopherol, $\gamma$-tocopherol, THF e 5FTHF) to the samples. The quantity of standard added varied between $50 \%$ and $100 \%$ of the initial content observed in buriti pulp. The recovery percentage was calculated using the equation: $\{\%$ recovery $=[($ final content of compound - content of standard added)/(initial content of compound) $\times 100\}$. All procedures were performed in triplicate (Hamacek et al., 2013a).

The linearity range of compounds was determined by injection, in duplicate, of six standard solutions with different concentrations using the same chromatographic conditions employed for extract analysis. Data obtained for the peak areas were used for linear regression analysis. The coefficient of determination $\left(\mathrm{R}^{2}\right)$ obtained in each case was used to evaluate the linearity (Lanças, 2004; Hamacek et al., 2013a).

Repeatability tests were performed by extraction and analysis, in quintuplicate, of the same repetition containing the compounds identified. The repeatability was evaluated by calculating the relative standard deviation (RSD) of the peak areas and retention times of the analyzed componentes (Lanças, 2004). Evaluation of the LOD was performed by successive dilutions of standards followed by determination of the smallest detectable amount. The LOD was established 3 times the amplitude of the baseline noise and the LOQ 10 times the LOD (Catharino et al., 2006; Hamacek et al., 2013a).

\subsection{Experimental design and statistical analysis}

A completely randomized design with five repetitions was used for analyses of the content of carotenoids and vitamins, with three repetitions for physical and physicochemical analyses. Data was stored in spread sheets using the Microsoft Office Excel software system, version 2007. Calculations of means, standard deviations and range of parameters was performed using SAS software (Statistical Analysis System), version 9.2 (2008), licensed to the Federal University of Viçosa (UFV), Minas Gerais, Brazil.

\section{Results and discussion}

\subsection{Physical and physicochemical characterization}

The buriti fruits presented themselves as slightly oval drupes, covered by extremely hard scales, of red-brown colour. In its interior was observed the presence of a nut covered by a fibrous peel and yellow pulp, meaty and oily.

The diameter of the fruits varied from 4.0 to $4.9 \mathrm{~cm}$ and the height from 4.8 to $6.8 \mathrm{~cm}$. Cândido \& Silva (2017) analyzing buriti fruits from two diferents biomes of Brazil showed diameter values ranging from 3.67 to $5.17 \mathrm{~cm}$ and the height ranging from 4.48 to $5.73 \mathrm{~cm}$. The buritis presented medium weight of the whole fruit, pulp, peel and seeds of $60.43,13.55,15.68$ and $31.19 \mathrm{~g}$, 
respectively. The mass of the pulp varied from 9.57 to $19.56 \mathrm{~g}$, with a yield of $22.7 \%$. Another study found a lower mass value than the present study (ranging from 3.00 to $7.48 \mathrm{~g}$ ) (Cândido \& Silva, 2017). The yield found in the present study was different from related studies by other researchers of buriti fruit from the Brazilian Cerrado. Cândido \& Silva (2017) in study with fruits of the same species, observed inferior yield (16.43\% and 8.53\%) in pulp grown in Goiás and Pará, respectively.

The buriti pulp yield from the Cerrado of Minas Gerais was also superior to the $10.98 \%$ related by Carneiro \& Carneiro (2011) in fruits collected on the state of Piauí, in areas with vegetation typical is Cerrado; it was, however, inferior to the $25.0 \%$ found by Carvalho \& Müller (2005) in fruits from Amazônia. Cerrado fruits are not domesticated and therefore their chemical content and physical characteristics may vary significantly. These characteristics may be affected by the edaphoclimatic characteristics of the fruit collection sites (Hamacek et al., 2013b).

Relatively to the contents of SS, TA and $\mathrm{pH}$ in the buriti pulp (Table 1) was observed content of SS to $13.67^{\circ}$ Brix lower reported by Castro et al. (2014) but it was higher than $4.33^{\circ}$ Brix

Table 1. Physicochemical characteristics and total energy of buriti pulp (Mauritia vinifera) from the Cerrado (Januária, Minas Gerais, Brazil).

\begin{tabular}{|c|c|}
\hline Variables $^{\mathrm{a}}$ & $\operatorname{Mean}^{\mathrm{b}} \pm \mathrm{SD}^{\mathrm{c}}$ \\
\hline Soluble solids ( ${ }^{\circ}$ Brix $)$ & $7.03 \pm 0.55$ \\
\hline Titratable acidity (g citric acid. $100 \mathrm{~g}^{-1}$ ) & $1.42 \pm 0.02$ \\
\hline Soluble solids / titratable acidity & $4.91 \pm 0.42$ \\
\hline $\mathrm{pH}$ & $3.59 \pm 0.06$ \\
\hline Moisture (g.100 g $\mathrm{g}^{-1}$ ) & $74.86 \pm 0.12$ \\
\hline Ash $\left(\mathrm{g} .100 \mathrm{~g}^{-1}\right)$ & $0.66 \pm 0.08$ \\
\hline Proteins (g.100 g $\mathrm{g}^{-1}$ ) & $1.00 \pm 0.02$ \\
\hline Total dietary fiber $\left(\mathrm{g} .100 \mathrm{~g}^{-1}\right)$ & $9.23 \pm 0.23$ \\
\hline Lipids (g.100 g ${ }^{-1}$ ) & $12.13 \pm 0.26$ \\
\hline Carbohydrates (g.100 g $\left.{ }^{-1}\right)$ & $2.10 \pm 0.50$ \\
\hline Total energy value (kcal.100 g-1) & $121.65 \pm 0.20$ \\
\hline
\end{tabular}

${ }^{\mathrm{a}}$ values expressed as fresh weight; ${ }^{\mathrm{b}}$ mean of 3 repetitions; ${ }^{\mathrm{c}}$ standard deviation. found by Schiassi et al. (2018). About the TA, an observation has been made showing a higher value than the $0.47 \mathrm{~g}$ of citric acid.100 $\mathrm{g}^{-1}$ reported by Schiassi et al. (2018) in buriti from São Paulo state. However, this content was similar to $1.48 \mathrm{~g}$ citric acid.100 $\mathrm{g}^{-1}$ observed by Castro et al. (2014) in fruits collected in Brazil. The pulp of buriti presented $\mathrm{pH}$ similar to the 3.5 found in the pulp of fruits collected in the Amazon (Vásquez-Ocmín et al., 2010) (Table 1).

The moisture concentration was similar to that observed by Schiassi et al. (2018), in fruits of area of the São Paulo state, Brazil and also observed by Cândido \& Silva (2017). Regarding

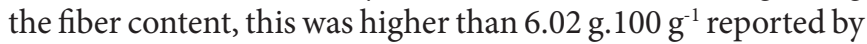
Schiassi et al. (2018) and higher than 6.69 observed in another study (Cândido \& Silva, 2017). (Table 1). The concentration of lipids found in the buriti pulp was greater than $7.72 \mathrm{~g} .100 \mathrm{~g}^{-1}$ reported by Schiassi et al. (2018). However, this was less than 19.00 g. $100 \mathrm{~g} \mathrm{~g}^{-1}$ found by Darnet et al. (2011) in fruits of the same species collected from different Brazilian states that have the Cerrado biome as predominant. The consumption of fruit sources of lipids is important, since these consist especially of fatty acids which play important roles in the structure of cell membranes and in metabolic processes, and act in the transport of fat soluble vitamins and to be hormone precursors (Welte \& Gould, 2017).

\subsection{Carotenoids and vitamins}

Tests for quality control demonstrated that the analysis conditions were reliable, which reduced the possibility of vitamin losses during extraction and analysis, and allowed the detection of small concentrations of the compounds analyzed (Table 2) (Hamacek et al., 2013b).

The recovery of the patterns added to the analyzed samples ranged from $95.2 \%$ to $99.9 \%$. The compounds found in the fruit showed relative standard deviation (RSD) of the peak areas and retention times ranging between $0.07 \%$ is $2.56 \%$, which leads to the conclusion that these results are more reliable. The limit of detection (LOD) for vitamins and carotenoids varied between 0.002 and $12.321 \mu \mathrm{g} \cdot \mathrm{mL}^{-1}$, suggesting that very small quantities

Table 2. Repeatability, limit of detection and quantification, linearity range and recovery of vitamins in the pulp of de buriti (Mauritia vinifera) from the Cerrado (Januária, Minas Gerais, Brazil).

\begin{tabular}{|c|c|c|c|c|c|c|}
\hline \multirow[b]{2}{*}{ Compounds } & \multicolumn{2}{|c|}{ Repeatability } & \multirow[b]{2}{*}{$\begin{array}{c}\mathrm{LOD}^{\mathrm{c}} \\
\left(\mu \mathrm{g} \cdot \mathrm{mL}^{-1}\right)\end{array}$} & \multirow{2}{*}{$\begin{array}{c}\mathrm{LOQ}^{\mathrm{d}} \\
\left(\mu \mathrm{g} \cdot \mathrm{mL}^{-1}\right)\end{array}$} & \multirow[b]{2}{*}{$\begin{array}{c}\text { Linearity range } \\
(\mu \mathrm{g})\end{array}$} & \multirow[b]{2}{*}{$\begin{array}{c}\text { Recover } \\
(\%)\end{array}$} \\
\hline & $\begin{array}{c}\text { Peak area } \\
(\mathrm{RSD})^{\mathrm{a}}\end{array}$ & $\begin{array}{c}\mathrm{RT}^{\mathrm{b}} \\
(\mathrm{RSD})\end{array}$ & & & & \\
\hline a-carotene & 2.41 & 0.24 & 7.861 & 78.612 & $0.0134-0.3935$ & 95.2 \\
\hline AA & 2.15 & 1.74 & 12.321 & 123.214 & $0.1550-7.7500$ & 96.4 \\
\hline a-tocopherol & 1.44 & 0.07 & 0.025 & 0.251 & $0.0010-0.1042$ & 99.9 \\
\hline$\gamma$-tocopherol & 2.08 & 0.54 & 0.025 & 0.252 & $0.0035-0.1040$ & 99.9 \\
\hline THF & 1.67 & 1.41 & 0.003 & 0.031 & $0.00004-0.04622$ & 97.9 \\
\hline 5-FTHF & 2.56 & 0.94 & 0.002 & 0.021 & $0.00003-0.03312$ & 95.7 \\
\hline
\end{tabular}

a Relative standard deviation; 'betention times; 'LOD: detection limit; ${ }^{\mathrm{d} L O Q}$ : Limit of quantification. AA: ascorbic acid; THF:tetrahydrofolate; 5-MTHF: 5-methyltetrahydrofolate; 5-FTHF:5-formyltetrahydrofolate. 
can be detected by the method used. The limit of quantification, considered as 10 times the $\mathrm{LD}$ value ranged from 0.02 to 123.21 $\mu$ g. $\mathrm{mL}^{-1}$ (Table 2).

The linear range of the examined compounds showed a correlation coefficient (R2) of greater than 0.993. In the pulp of buriti it was identified the presence of $\alpha$-carotene (retention time - TR: 9.75 minutes), $\beta$-carotene (TR: 10.22 minutes); AA (RT: 3.85 minutes); atocopherol (RT: 7.82 minutes), $\alpha$-tocotrienol (TR: 9.23 minutes), $\beta$-tocopherol (RT: 12.20 minutes), $\gamma$-tocopherol (RT: 12.89 minutes), THF (RT: 8.01 minutes) and 5-FTHF (TR: 19.51 minutes). It has been identified in samples of burity $\beta$-cryptoxanthin, lycopene, $\delta$-tocopherol, $\beta$-, $\gamma$ - and $\delta$-tocotrienol and 5MTHF (Figure 1).

Studies about the concentration of carotenoids, vitamin C, vitamin $\mathrm{E}$ and folate in fruits of Buriti of the Cerrado of Minas Gerais are not found in the literature. Comparing the carotenoid concentrations in fruits collected in other states of Brazil, it was observed that the concentration found in this study was superior to $4.65 \mathrm{mg} \beta$-carotene $100 \mathrm{~g}^{-1}$ observed by Schiassi et al. (2018), buriti in the São Paulo region. However, the concentration was less than the one found by Rodriguez-Amaya et al. (2008) (46.6 mg. $100 \mathrm{~g}^{-1}$ ) in the Piauí state fruit.

The pulp of buriti in the state of Minas Gerais presented concentration of carotenoids about nine times higher than that one found in carrots $\left(2.8 \mathrm{mg} .100 \mathrm{~g}^{-1}\right)$ and five times larger than those observed in cabbage $\left(4.9 \mathrm{mg}^{1} 100 \mathrm{~g}^{-1}\right)$ (Rodriguez-Amaya et al., 2008), vegetables traditionally known as a major source of provitamin A. In relation to the main fruits consumed by the population as sources of carotenoids, the fruits of buriti evaluated in our study had more than eight times the concentration of carotenoids of acerola $\left(2.97 \mathrm{mg} .100 \mathrm{~g}^{-1}\right)$ and papaya (2.87 mg.100 $\mathrm{g}^{-1}$ ) and 2 times the level found in cherry (13.5 mg.100 g ${ }^{-1}$ ) (Rodriguez-Amaya et al., 2008) (Table 3).

Using the conversion factors of the pro-vitamin A carotenoids (Institute of Medicine, 2001), it was found that the buriti pulp showed Vitamin value much greater than that found in fruits

Table 3. Carotenoids and vitamin contents in 100 grams of buriti pulp (Mauritia vinifera) from the Cerrado (Januária, Minas Gerais, Brazil).

\begin{tabular}{|c|c|c|}
\hline Compounds ${ }^{\mathrm{a}}$ & $\operatorname{Mean}^{\mathrm{b}} \pm \mathrm{SD}^{\mathrm{c}}$ & $\%$ \\
\hline Carotenoids (mg.100 g ${ }^{-1}$ ) & $23.94 \pm 7.17$ & 100.0 \\
\hline$\alpha$-carotene (mg.100 g $\left.\mathrm{g}^{-1}\right)$ & $2.30 \pm 0.41$ & 9.61 \\
\hline$\beta$-carotene $\left(\mathrm{mg} .100 \mathrm{~g}^{-1}\right)$ & $21.64 \pm 6.77$ & 90.38 \\
\hline Vitamin A (RAE. $100 \mathrm{~g}^{-1}$ ) & $1899.33 \pm 581.31$ & - \\
\hline Vitamin C (mg.100 g $\left.{ }^{-1}\right)$ & $59.93 \pm 5.32$ & 100.0 \\
\hline $\mathrm{AA}\left(\mathrm{mg} \cdot 100 \mathrm{~g}^{-1}\right)$ & $51.85 \pm 3.44$ & 86.5 \\
\hline DHA (mg.100 g-1) & $8.08 \pm 5.37$ & 13.5 \\
\hline Vitamin $E\left(\mu \mathrm{g} \cdot 100 \mathrm{~g}^{-1}\right)$ & $6454.73 \pm 897.42$ & 100.0 \\
\hline a-tocopherol $\left(\mu \mathrm{g} .100 \mathrm{~g}^{-1}\right)$ & $4988.81 \pm 1011.49$ & 71.1 \\
\hline$\alpha$-tocotrienol $\left(\mu \mathrm{g} .100 \mathrm{~g}^{-1}\right)$ & $159.17 \pm 35.32$ & 2.5 \\
\hline$\beta$-tocopherol $\left(\mu \mathrm{g} .100 \mathrm{~g}^{-1}\right)$ & $743.66 \pm 528.05$ & 11.5 \\
\hline$\gamma$-tocopherol $\left(\mu \mathrm{g} .100 \mathrm{~g}^{-1}\right)$ & $579.08 \pm 221.15$ & 8.9 \\
\hline Folates $\left(\mu \mathrm{g} .100 \mathrm{~g}^{-1}\right)$ & $53.08 \pm 7.41$ & 100.0 \\
\hline THF $\left(\mu \mathrm{g} .100 \mathrm{~g}^{-1}\right)$ & $23.23 \pm 4.78$ & 43.8 \\
\hline 5-FTHF $\left(\mu \mathrm{g} .100 \mathrm{~g}^{-1}\right)$ & $29.83 \pm 4.68$ & 56.2 \\
\hline
\end{tabular}

${ }^{a}$ values expressed as fresh weight; ${ }^{b}$ mean of 5 repetitions; 'standard deviation. AA: ascorbic acid; DHA: dehydroascorbic acid; THF: tetrahydrofolate; 5-FTHF: 5-formyltetrahydrofolate.
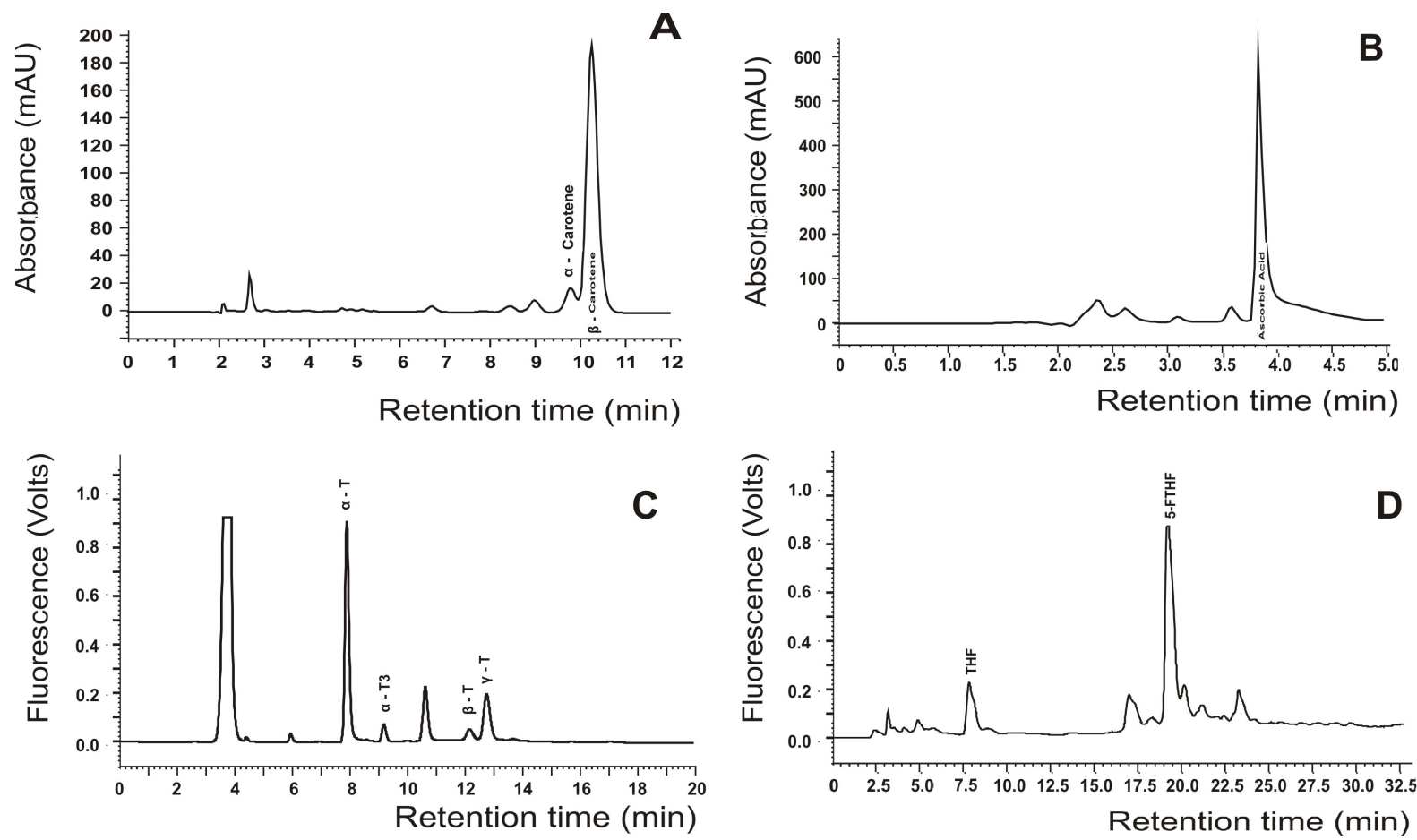

Figure 1. HPLC analysis of carotenoids (A), vitamin C (B), vitamin E (C) and folate (D) in buriti pulp (Mauritia vinifera) from the Cerrado (Januária, Minas Gerais, Brazil). $\alpha$-T: $\alpha$-tocopherol; $\alpha$-T3: $\alpha$-tocotrienol; $\beta$-T: $\beta$-tocoferol; $\gamma$-T: $\gamma$-tocoferol.THF: tetrahydrofolate,5-FTHF: 5-formyltetrahydrofolate. Chromatographic conditions are shown in the materials and methods section. 
traditionally consumed by the population, such as acerola (175.0 RAE.100 g ${ }^{-1}$ ), sweet passionfruit (89.5 RAE.100 g ${ }^{-1}$ ), papaya (76.7 RAE. $100 \mathrm{~g}^{-1}$ ), and persimmon (58.4 RAE. $100 \mathrm{~g}^{-1}$ ) (Souza et al., 2004). Judging by the substantial content of carotenoids found in Buriti on the Cerrado of Minas Gerais, this fruit can be considered as a food with high pro-vitamin A content mainly due to the concentration of $\beta$-carotene in its pulp. Especially in developing countries where vitamin A deficiency is considered one of the most serious public health problems, consumption of Buriti should be encouraged.

The buriti from Minas Gerais presented vitamin C concentration higher than observed by Schiassi et al. (2018) (7.42 mg.100 g ${ }^{-1}$ ) in buriti grown in São Paulo state. The same was observed in fruits of Minas Gerais Cerrado as jatoba (Hymenaea stigonocarpa) (8.91 mg.100 g ${ }^{-1}$ ) (Cardoso et al., 2013a), pequi (Caryocar brasiliense Camb.) (14.33 mg.100 g ${ }^{-1}$ ) (Cardoso et al., 2013b), and tamarind (Tamarindus indica L.) (4.79 mg.100 g $\left.{ }^{-1}\right)$ (Hamacek et al., 2013a).

Relative to fruits traditionally known to the population as sources of vitamin C, such as orange $\left(47.8 \mathrm{mg} .100 \mathrm{~g}^{-1}\right)$, lemon (34.5 mg.100 g ${ }^{-1}$ ) and passion fruit (19.8 mg.100 g $\mathrm{g}^{-1}$ ) (United States Department of Agriculture, 2015), the concentration observed in buriti was also higher. Thus, it can be said that the consumption of buriti could contribute to the reduction of chronic diseases due to the antioxidant effect that vitamin C plays in the body.

In the buriti pulp, the a-tocopherol was the major component, accounting for $71.1 \%$ of the total concentration of vitamin $\mathrm{E}$. The vitamin $\mathrm{E}$ concentrations observed in Buriti were higher than those found in other fruits of the Cerrado, such mangaba (Hancornia speciosa) (2732.47 $\left.\mu \mathrm{g} .100 \mathrm{~g} \mathrm{~g}^{-1}\right)$ (Cardoso et al., 2014), jatoba (495.54 $\mu \mathrm{g} .100 \mathrm{~g}^{-1}$ ) (Cardoso et al., 2013a), pequi (170.81 $\left.\mu \mathrm{g} .100 \mathrm{~g}^{-1}\right)$ (Cardoso et al., 2013b) and tamarind (108.78 $\left.\mu \mathrm{g} .100 \mathrm{~g} \mathrm{~g}^{-1}\right)$ (Hamacek et al., 2013a) and in also relative to fruits popularly consumed as sources of vitamin E, such as avocado (2750 $\left.\mu \mathrm{g} .100 \mathrm{~g}^{-1}\right)$ (United States Department of Agriculture, 2015). The concentration of vitamin E was also

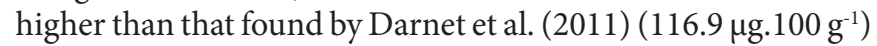
in fruits of the same species found in the state of Pará, Brazil.

Between the folates investigated in the pulp of buriti, THF and 5-FTHF was found, which accounted for $43.8 \%$ and $56.2 \%$ of the total concentration respectively. The folates concentration that was observed in buriti was greater than that found in fruits often consumed by the population such as orange

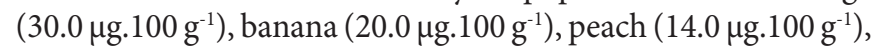
grape $\left(4.0 \mu \mathrm{g} .100 \mathrm{~g}^{-1}\right)$ and apple $\left(3.0 \mu \mathrm{g} .100 \mathrm{~g}^{-1}\right)$ (United States Department of Agriculture, 2015), and also higher than that found in other fruits from the cerrado, like pequi $\left(5.16 \mu \mathrm{g} .100 \mathrm{~g}^{-1}\right)$ (Cardoso et al., 2013b). However, it was less than that observed in tamarind (59.35 $\mu \mathrm{g} .100 \mathrm{~g}^{-1}$ ) (Hamacek et al., 2013a). No studies evaluating the folate concentrations in Buriti were found, which prevented a comparison with our results.

\section{Conclusion}

The pulp of buriti showed high concentrations of fiber, vitamin $\mathrm{A}$, vitamin $\mathrm{C}$, vitamin $\mathrm{E}$ and folate, being considered an excellent source of these components. Because of its nutritional value, the fruits of buriti found in the Cerrado of Minas Gerais, Brazil can contribute to the adequacy of intake of fiber and vitamins and to reduce the incidence of several disorders, such as hypovitaminosis and chronic diseases, particularly those most frequently in native populations of the Cerrado of Minas Gerais.

\section{Acknowledgement}

The authors thank the CNPq and FAPEMIG, Brazil, for granting of scientific initiation and Master's program scholarships, as well as for the research financial support.

\section{References}

Almeida, S. P., Proença, C. E. B., Sano, S. M., \& Ribeiro, J. F. (1998). Cerrado: espécies vegetais úteis. Planaltina: Embrapa.

Association of Official Analytical Chemists - AOAC. (2012). Official methods of analysis of the Association of Official Analytical Chemists (16th ed.). Washington: AOAC.

Campos, F. M., Ribeiro, S. M. R., Della Lucia, C. M., Pinheiro-Sant’Ana, H. M., \& Stringheta, P. C. (2009). Optimization of methodology to analyze ascorbic and dehydroascorbic acid in vegetables. Quimica Nova, 32(1), 87-91. http://dx.doi.org/10.1590/S0100-40422009000100017.

Cândido, T. L. N., \& Silva, M. R. (2017). Comparison of the physicochemical profiles of buriti from the Brazilian Cerrado and the Amazon region. Food Science and Technology (Campinas), 37(1), 1-5.

Cardoso, L. M., Bedetti, S. F., Ribeiro, S. M. R., Esteves, E. A., \& Pinheiro-Sant'Ana, H. M. (2013a). Jatobá of the Cerrado (Hymenaea stigonocarpa): chemical composition, carotenoids and vitamins in an exotic fruit from the Brazilian Savannah. Fruits, 68(2), 95-107. http://dx.doi.org/10.1051/fruits/2013056.

Cardoso, L. M., Reis, B. D. L., Hamacek, F. R., \& Pinheiro-Sant'Ana, H. M. (2013b). Chemical characteristics and bioactive compounds of of cooked pequi fruits (Caryocar brasiliense Camb.) from the Brazilian Cerrado. Fruits, 68(1), 3-14. http://dx.doi.org/10.1051/ fruits/2012047.

Cardoso, L. M., Reis, B. L., Oliveira, D. S., \& Pinheiro-Sant’Ana, H. M. (2014). Mangaba (Hancornia speciosa Gomes) from the brazilian cerrado: nutritional value, carotenoids and antioxidant vitamins. Fruits, 69(2), 89-99. http://dx.doi.org/10.1051/fruits/2013105.

Carneiro, T. B., \& Carneiro, J. G. M. (2011). Frutos e polpa desidratada Buriti (Mauritia flexuosa L.): aspectos físicos, químicos e tecnológicos. Revista Verde de Agroecologia e Desenvolvimento Sustentável, 6(2), 105-111.

Carvalho, J. E. U., \& Müller, C. H. (2005). Biometria e rendimento percentual de polpa de frutas nativas da Amazônia. Brasília: Embrapa.

Castro, D. Z., Sousa, E. P., Nunes, J. S., Silva, L. M. M., \& Moreira, I. S. (2014). Caracterização física e físico-química de polpa de buriti (Mauritia flexuosa). Revista Verde de Agroecologia e Desenvolvimento Sustentável, 9, 117-120.

Catharino, R. R., Godoy, H. T., \& Lima-Pallone, J. A. (2006). Metodologia analítica para determinação de folatos e ácido fólico em alimentos. Quimica Nova, 29(5), 972-976. http://dx.doi.org/10.1590/S010040422006000500016 .

Darnet, S. H., Silva, L. H. M., Rodrigues, A. M. C., \& Lins, R. T. (2011). Nutritional composition, fatty acid and tocopherol contents of buriti (Mauritia flexuosa) and patawa (Oenocarpus bataua) fruit pulp from the Amazon region. Food Science and Technology (Campinas), 31(2), 488-491. http://dx.doi.org/10.1590/S0101-20612011000200032. 
Della Lucia, C. M., Silva, E. R., Brandão, S. C. C., Ribeiro, S. M. R., \& Pinheiro-Sant'Ana, H. M. (2010). Otimização de método para análise de folatos em hortaliças folhosas por cromatografia líquida de alta eficiência com detecção por fluorescência. Quimica Nova, 34(1), 335-340.

Galli, F., Azzi, A., Birringer, M., Cook-Mills, J. M., Eggersdorfer, M., Frank, J., Cruciani, G., Lorkowski, S., \& Özer, N. K. (2017). Vitamin E: Emerging aspects and new directions. Free Radical Biology \& Medicine, 102, 16-36. http://dx.doi.org/10.1016/j.freeradbiomed.2016.09.017. PMid:27816611.

Hamacek, F. R., Martino, H. S. D., \& Pinheiro-Sant’Ana, H. M. (2014). Murici, fruit from the Cerrado of Minas Gerais, Brazil: physical and physicochemical characteristics, and occurrence and concentration of carotenoids and vitamins. Fruits, 69(6), 459-472. http://dx.doi. org/10.1051/fruits/2014032.

Hamacek, F. R., Santos, P. R. G., Cardoso, L. M., \& Pinheiro-Sant'Ana, H. M. (2013a). Nutritional composition of tamarind (Tamarindus indica L.) from the Cerrado of Minas Gerais, Brazil. Fruits, 68(5), 381-395. http://dx.doi.org/10.1051/fruits/2013083.

Hamacek, F. R., Santos, P. R. G., Cardoso, L. D. M., Ribeiro, S. M. R., \& Pinheiro-Sant'Ana, H. M. (2013b). 'Araçá of Cerrado' from the Brazilian Savannah: physical characteristics, chemical composition, and content of carotenoids and vitamins. Fruits, 68(6), 467-481. http://dx.doi.org/10.1051/fruits/2013095.

Institute of Medicine - IOM. (2001). Food and nutrition board, standing committee on the scientific evaluation of dietary reference intakes Dietary reference intakes: for vitamin A, vitamin K, Arsenic, Boron, Cromium, Copper, Iodine, Iron, Manganese, Molybdenium, Nickel, Silicon, Vanadium and Zinc. Washington: National Academy Press.

Lanças, F. M. (2004). Validação de métodos cromatográficos de análise (6th ed.). São Carlos: Rima:.

Mangialasche, F., Xu, W., Kivipelto, M., Costanzi, E., Ercolani, S., Pigliautile, M., Cecchetti, R., Baglioni, M., Simmons, A., Soininen, H., Tsolaki, M., Kloszewska, I., Vellas, B., Lovestone, S., Mecocci, P., \& AddNeuroMed Consortium (2012). Tocopherols and tocotrienols plasma levels are associated with cognitive impairment. Neurobiology of Aging, 33(10), 2282-2290. http://dx.doi.org/10.1016/j. neurobiolaging.2011.11.019. PMid:22192241.

Pardauil, J. J., Molfetta, F. A., Braga, M., Souza, L. K., Geraldo, N. R. Fo., Zamian, J. R., \& Costa, C. E. F. (2017). Characterization, thermal properties and phase transitions of amazonian vegetable oils. Journal of Thermal Analysis and Calorimetry, 127(2), 1221-1229. http:// dx.doi.org/10.1007/s10973-016-5605-5.

Pearson, J. F., Pullar, J. M., Wilson, R., Spittlehouse, J. K., Vissers, M., Skidmore, P. M., Willis, J., Cameron, V. A., \& Carr, A. C. (2017). Vitamin $\mathrm{C}$ status correlates with markers of metabolic and cognitive health in 50-year-olds: findings of the CHALICE cohort study. Nutrients, 9(8), 831. http://dx.doi.org/10.3390/nu9080831. PMid:28771190.

Pinheiro-Sant'Ana, H. M., Guinazi, M., Oliveira, D. S., Della Lucia, C. M., Reis, B. L., \& Brandão, S. C. C. (2011). Method for simultaneous analysis of eight vitamin $\mathrm{E}$ isomers in various foods by high performance liquid chromatography and fluorescence detection. Journal of Chromatography. A, 1218(47), 8496-8502. http://dx.doi. org/10.1016/j.chroma.2011.09.067. PMid:22014383.

Pinheiro-Sant'Ana, H. M., Stringheta, P. C., Brandão, S. C. C., \& Azeredo, R. M. C. (1998). Carotenoid retention and vitamin A value in carrot (Daucus carota L.) prepared by food servisse. Food Chemistry, 61(1), 145-151. http://dx.doi.org/10.1016/S0308-8146(97)00084-8.

Refsum, H., \& Smith, A. D. (2017). Folic acid for the prevention of neural tube defects. JAMA Pediatrics, 171(7), 710-711. http://dx.doi. org/10.1001/jamapediatrics.2017.0866. PMid:28558107.

Rodriguez-Amaya, D. B., Kimura, M., \& Amaya-Farfan, G. (2008). Fontes brasileiras de carotenoids: tabela brasileira de composição de carotenoides em alimentos. Brasília: Ministério do Meio Ambiente.

Rodriguez-Amaya, D. B. (1999). Latin American food sources of carotenoids. Archivos Latinoamericanos de Nutricion, 49(3, Suppl. 1), 74-84. PMid:10971848.

Schiassi, M. C. E. V., Souza, V. R., Lago, A. M. T., Campos, L. G., \& Queiroz, F. (2018). Fruits from the Brazilian Cerrado region: physico-chemical characterization, bioactive compounds, antioxidant activities, and sensory evaluation. Food Chemistry, 245, 305-311. http://dx.doi.org/10.1016/j.foodchem.2017.10.104. PMid:29287376.

Souza, S. L., Moreira, A. P. B., Pinheiro-Sant'Ana, H. M., \& Alencar, E. R. (2004). Carotenes and provitamin A contents of fruits commercialized in Viçosa, MG. Acta Scientiarum. Agronomy, 26(4), 453-459.

United States Department of Agriculture - USDA. (2015). Food and nutrition information center [online]. Beltsville: USDA. Retrieved from http://www.nal.usda.gov/ fnic/foodcomp/data/

Vásquez-Ocmín, P. G., Alvarado, L. F., Solís, V. S., Torres, R. P., \& Mancini, J. Fo. (2010). Chemical characterization and oxidative stability of the oils from three morphotypes of Mauritia flexuosa Lf, from the Peruvian Amazon. Grasas y Aceites, 61(4), 390-397. http://dx.doi.org/10.3989/gya.010110.

Welte, M. A., \& Gould, A. P. (2017). Lipid droplet functions beyond energy storage. Biochimica et Biophysica Acta (BBA)-. Molecular and Cell Biology of Lipids, 1862(10), 1260-1272. http://dx.doi. org/10.1016/j.bbalip.2017.07.006.

Yamagata, K. (2017). Carotenoids regulate endothelial functions and reduce the risk of cardiovascular disease. In D. Cvetkovic \& G. Nikolic (Eds.), Carotenoids. London: InTech. http://dx.doi.org/10.5772/67464. 